\title{
Corporate Social Responsibility in Garment Industry Supply Chain
}

\author{
M. Hasan \\ School of Mechanical and \\ Manufacturing Engineering \\ UNSW, Sydney \\ Y. Shi \\ School of Mechanical and \\ Manufacturing Engineering \\ UNSW, Sydney
}

\begin{abstract}
There has been a growing concern over the ready-made garment (RMG) industry in their environmental and social performance. Each stakeholder involved in the garment supply chain has embarked on Corporate Social Responsibility (CSR) practices in responding to the criticism of poor working conditions. This thesis reviews the history of the RMG industry and highlights the problems such as environmental issues, workers' low wages and hazardous work environment raised with the development of the garment industry in developing countries. CSR concept is reviewed from the aspects of its importance, implementation and related challenges. Some of the main apparel exporters (e.g. China, India and Bangladesh) are analyzed in their current situation of the industry and related CSR practices. It is found that CSR is still at an early stage, regulations are generally not comprehensive and workers are in poor working conditions in the RMG industry of developing countries. Based on what are found in the different cases, the collaboration between each stakeholder seems of importance to improve current conditions. Not only garment manufacturers themselves, but also the government, buyers, none-government organizations (NGO) and consumers are responsible for supporting the RMG industry towards a more socially responsible direction. A framework is established to illustrate the relationship and necessary collaboration between the stakeholders.
\end{abstract}

Keywords: Garment, Industry, Environment, Social, Responsibility

\section{INTRODUCTION}

The garment industry is one of the largest industries in the world. With the development of the industry in developing countries, both environmental and social problems occur due to the neglect of CSR. Globalization makes clothing to be affordable at increasingly low price, however it has negative impact on environment throughout the life cycle of it [1]. During the production of clothing, vast energy is consumed and considerable amount of wastes including sewage and used clothing are generated. Obviously it increases the burden to the environment. In addition, poor working and living condition is another outcome from the RMG industry as it is laborintensive. Poor labour standards include low wages, long working hours, hazardous work environment, workplace abuse and being excluded from unions. In 2012, average wage of the workers in countries such as Bangladesh, Vietnam and Cambodia is even less than $\$ 0.4$ per hour [2]. A report from ILO [3] shows that 22\% of the global workforce meaning 614.2 million people still work more than the limit of 48-hour per week and 8-hour per day. These conditions make garment workers' life tough when regulations or labour laws do not protect them. The government and Western buys are blamed to be inactive in ensuring labor rights 
and workers' safety and health. The typical example recently is the collapse of Rana Plaza building in Bangladesh, where over 1100 workers lost their life in this tragedy [4].

A framework seems necessary for not only Bangladesh, but other apparel exporters around the world to implement CSR practices in order to create a good working condition for garment workers. The main problem may lie in with whose responsibility should CSR be implemented in the industry. Stakeholders such as the government, garment buyers, suppliers and NGOs are considered to act the role in conducting CSR practices. Each of the stakeholders may have their own shortages and strengths in the action. The government imposes regulations and labour standards but maybe lack of professionals in a specific section. While NGOs are able to access to different resources, however they do not have legal effect. In order to take a deep look at the RMG industry, cases in different developing countries may provide an insight on understanding the barriers of implementing CSR practices and establishing a framework to tackle CSR issues. Some of the main apparel exporters such as China, India and Bangladesh are chosen to be analyzed in its current situations. Based on the problems found in the cases, improvement recommendations can be raised to build up a framework clarifying the responsibility of the stakeholders and the collaboration among the stakeholders that can exist to improve poor working conditions in the RMG industry in developing countries.

\section{LITERATURE REVIEW}

The aim of the literature review is to review the history of the apparel and the ready-made garment industry and to show the relationship between the development of the industry and the problems such as environment issues and labour conditions occurred due to the development. The first section reviews the background of the textiles and apparel industry, the industrialization of the industry as well as the global commodity chain. The second section discusses about the environmental impact throughout the whole life cycle of a garment from cradle to grave. The third section talks about social impact of garment industry on factory workers from the aspects of working hours, wage rate, working conditions and so forth. The fourth section is about corporate social responsibility from the aspects of definition, benefits, codes of conduct, challenges and so forth.

\section{Background of the Apparel and Textiles Industry}

The history of clothing can be traced back to 83,000 to 170,000 years ago [5]. It provides functions such as protection from weather, safety enhancement, and appearance. Clothing also has functions for social and cultural purposes. It can be used to indicate social status and to distinguish gender and occupation. The material ranges from cotton, animal skin, wool to plastic and others depending on the requirement of the products.

\section{Industrialization of the Industry}

Before $18^{\text {th }}$ century, textile cottage industry was based on human labour, and until English inventors started producing cloth mechanically, the industry was automated [6]. According to the website of globalEDGE, not until the industrial evolution, the textile industry had been experiencing quite slow development and a lack of progress. After technology development was accelerated by the demand, the textile industry had been mechanized incorporating with the use of automation.

On the other hand, the apparel industry, as it relied on human labour, the problem was mainly on looking for cheaper labor market. Since the rapid change of fashion, the garment industry is very unlikely to be automated [7]. This fact leads to the apparel industry pursuing large and low labour cost supply to sew apparel [8]. In the 1990s, garment retailers started increasing products ranges, focusing on more fashion design, developing distinct brands and moving 
production to lower costs overseas. This shift provided those developing countries with abundant employment opportunities especially for woman. However the economic crisis in 2008 threatened the stability of the labour market over the world, 3 million workers lost their jobs [3]. The increased competition among the retailers divided the industry into two sectors, high-end and low-end production and brands. Where high-end production uses better technology and skilled workers, low-end production pursues low cost and therefore leading to poor working conditions [3]. This is going to be further discussed in this report regarding to the labour market overseas since the trend towards moving manufacturing base to regions where have lower labour cost. For developing nations, as the low fixed cost to start, the apparel industry is a typical start [7]. Kozlowski [7] presents that the movement to offshore production in order to seek of low-cost labour may have negative environmental impact, but the opportunity exists that employment and the development of garment industry to be positive impacts on the developing countries.

\section{The Apparel Commodity Chain}

Globalization has changed the pattern of international trade, where the explosive growth of imports in developed countries shows that the production centers tends to move to newly industrializing economies in the Third World [9]. The economy largely relies on the export industrialization as the development strategy for those countries. Gereffi [9] also classified two types of international economic networks, which are 'producer-driven' and 'buyer-driven' commodity chains, between which the ready-made garment industry belongs to 'buyer-driven' chain. Unlike 'producer-driven' commodity chain, which derives the profit from scale, volume, and technological advances, profit of 'buyer-driven' commodity chains derive from 'unique combinations of high-value research, design, sales, marketing and financial services that allow the retailers, branded marketers and branded manufacturers to act as strategic brokers in linking overseas factories with evolving product niches in the main consumer markets' [9].

In the past, retailers were the customers of the apparel manufacturers, however this relationship turned into competitors since consumers required better value, therefore retailers paid their attention to import that provided better offer. With the time, oversea producers had been able to have all the capability required in every aspect of the production process, during that time and afterwards, there has undergone several production migration from North America and Western Europe to Japan, and from Japan to the Asian Big Three (Hong Kong, Taiwan and South Korea), and finally from the Asian Big Three to mainland China, South Asian counties, Sri Lanka and Latin America [9]. In 2012, according to International Labour Organization [3], China was the world biggest clothing exporter accounting for 38 percent of the world volume, followed by Bangladesh that took up 5\% of the share. The success of the commodity chain could not leave without OEM export as it enhances the ability of the manufacturers to know about the behavior of foreign buyers for example, price, quality and delivery. Although OBM production experienced great success in some countries where have good brand name for certain types of products, OEM still fits the manufacturers who have the core competence in manufacturing, $R \& D$ and design better. Because those OEM manufacturers can sell their products to the customers who have better brand name. In order to keep OEM production profitable, it is important to focus on manufacturing expertise and learning to manage oversea production flexibly [9].

\section{Environmental Impact}

Globalization makes clothing to be affordable at increasingly low price, however it has negative impact on environment throughout the life cycle of it [1]. 'The environmental footprint of creating apparel varies based on the methods used to produce and extract the resources; the 
process to create, dye and finish the materials; the steps to cut, sew and assemble the products, and the packaging and distribution systems to move and deliver the product'[10].

\section{Manufacturing Stage}

Take conventional cotton farming for example, cotton uses around $25 \%$ of the insecticides and $10 \%$ of the pesticides over the world. Some pesticides are regarded as hazardous by the World Health Organization since its impact on human, for example, sexual dysfunction, headaches, convulsions and even death. Farmers or workers who are exposed to the hazardous are very likely to be effected through nervous system, moreover, widespread of agricultural antibiotics will influence surface water and ground water including drinking water. In addition, since cotton is water sensitive crop, it consumes tremendous amount of water every year and majority of the cotton farming regions face water scarcity [10]. Another raw material that is widely used in apparel manufacturing is synthetic fibers. The manufacture of synthetic fibers is an energy-consuming process requiring large amounts of crude oil and releasing greenhouse gases as well as 'volatile organic compounds, particulate matter, and acid gases such as hydrogen chloride, all of which can cause or aggravate respiratory disease' [10][1].

\section{Usage Stage}

After the manufacturing stage, usage stage also has high impact on the environment. Washing, drying, and caring of the clothes are the factors determining to what extent clothing has imposed negative impact on the environment. Laundering has more environmental impact than the processing and producing of the fabric, as it is a frequent and lasting activity. Kozlowski [7] expresses that $82 \%$ of the energy use and $83 \%$ of the $\mathrm{CO} 2$ emissions are a result of the consumer use phase according to a LCA of a polyester blouse. Another analysis shown by Kozlowski [7] was that for a single T-shirt $60 \%$ of the energy used is related to laundry and high temperature drying [11].

\section{End of Life Stage}

Due to fast fashion and accelerated consumption rates, textile and apparel waste is increased at a rapid rate. Americans now purchase five times as much clothing as they did in 1980, which leads to 10.5 million tons of clothing is sent to landfill every year among which New York City contributes to 193,000 tons tossed annually [12]. These figures show that only a small portion of used clothing are turned to charity. In Britain, the figure is 1.5 million tons per year and UK residents spent US $\$ 71$ billion on clothes, $28 \%$ of the consumers admit that they bought more than they really need [7]. Not only consumer produce apparel waste after discarding their purchases, during the apparel production process there is also waste generation although there is no estimation for the exact amount.

\section{CSR in the Apparel Industry}

Dickson and Eckman [13] stated that CSR is relatively new to the apparel industry although it was conceptualized in the 1950s. Since there was no standardized definition on CSR for the apparel industry, the authors collected views from 74 professors and grad students to draw a definition on that: 'Socially responsible businesses consider the entire system of stakeholders associated with apparel supply chains, including production workers, sales help, and consumers, and the entire product life cycle from the inception of raw materials and components to product design, use and discard' [14]. Business for Social Responsibilities (BSR) further strengthened the concept of CSR in the apparel industry, business should be 'achieving commercial success in ways that honors ethical values and respects people, communities and the natural environment' [7]. Those definitions of CSR in the apparel industry had been identified by other researchers but in similar content, the commonality of these definitions suggests that firms should pursue values more than economic [15]. 
The apparel industry has been criticized for problems like labour abuses and low wages in the developing countries frequently. Kozlowski [7] claimed that there are numbers of forces that lead corporations to adopt CSR: customer demand, market competition, in response to public demands, a sense of moral obligation, potential cost reductions and government regulation. As a result, CSR is under more concerns because of those forces and implemented into corporate operation and strategies in order to maintain healthy relationship with stakeholders. From the aspect of stakeholders in the apparel industry, they are increasingly aware of the issues like worker rights, pollution, pesticide usage, labour working condition and other negative impacts coming with fast fashion, apparel brands have started focusing on business practices towards CSR. According to Sutantoputra [16], some stakeholders have genuine concern with the irresponsible behaviors since they create costs to the society. Therefore both internal and external stakeholders are increasingly imposing pressure on adopting a view that prioritizing social benefits over purely profit driven approach.

\title{
OBJECTIVES
}

The objective of this study is to understand corporate social responsibility in the ready-made garment industry and to investigate major problems occurred in the industry of developing countries since more and more companies in developed countries outsource the production oversea especially in counties where labor cost is low while working condition and human rights are of problem in countries such as in India, China, Bangladesh and other Asian countries. This condition has led to some tragedies like factory fire and labor abuse that result in poor life for workers and even death. Therefore a framework will be established to conduct CSR in developing countries based on previous research from the aspects of better working conditions and improved labor rights.

\section{METHODOLOGY}

As this study is to analyze CSR of the RMG industry in developing countries, several cases will be used to gather information about both current conditions and previous research results on implementing CSR. Qualitative method is used with multiple case studies such as Rana Plaza and Tazreen. In addition to that, the RMG industry in different countries will be analyzed to search for common problems that exist relating to the workers and historical researches on those countries will be used as guidance to develop the framework as a whole. These different cases that in the same sector allows an in-depth study revealing contemporary phenomenon in a real-life context.

\begin{abstract}
ANALYSIS
In this section, multiple studies will be discussed to collect information regarding to CSR issues in different developing countries. After that, the information such as labor problems and related solutions or suggestions will be viewed to support the establishment of the final framework to implement CSR.
\end{abstract}

\section{Corporate Social Responsibility Issues in China}

As the world's largest garment exporter, China has been criticized on its CSR issues such as labor standards and environmental protection. Two studies will be discussed in this section regarding to the relationship between CSR and human resource management (HRM) as well as incorporating CSR in a national context.

\section{CSR and Human Resource Management}

In regards to CSR in China, although China is the main supplier for apparel, their poor reputation on labour standards threatens corporate brands and its market [17]. Therefore 
there is pressure on China to implement CSR practice to address those issues. As result, the government has focused on engaging companies to involve in social and environmental practices to sustain the development in China. Cooke and He [17] presented that there are a number of laws and regulations have been released to ensure labors' right and conditions, including Trade Union Law and the Labour Contract Law. Although China is still at the starting stage to spread CSR with a standardized and systematic approach. Chan and Ross [18] stated that CSR is first introduced into China in the middle 1990s, when codes of conduct was imposed on suppliers and auditing them under the pressure of anti-sweatshop initiatives abroad. While some enterprises were reluctant to accept the CSR requirements, and until 2000s, the concept of CSR was under increasing attention and debate those companies and departments started to conduct CSR. The Chinese government held two influential forums that help to develop CSR which they believe could build a sustainable society. In addition to that, other organizations such as NGOs and Chinese academic institutions have put their effort on promoting CSR [17]. According to the authors, the condition of CSR in China is diverse. The analysis conducted by Cooke [19] revealed that 11 of the 30 companies among Top-50 Chinese Private Enterprises of 2004 reported adopting CSR activities. These activities includes 'sponsoring social events, organizing employees to take part in charity work, donations to education, environmental protection actions, providing jobs to disabled workers and laid-off workers, and supporting the development of the Western Region of China'. Cooke and He [17] revealed that comparing with western CEOs, Chinese CEOs were less focusing on issues like human rights, environmental problems and local culture, while employment creation and the influence on local communities were more of concern in CSR achievement.

In the Chinese apparel industry, several guidelines have been introduced to address CSR problems. According to ILO, these problems rely in incorporating labor and environmental standards into the business operations. The guidelines include such as the 'Development Guidelines for the Textile Industry in the $11^{\text {th }} 5$-year plan period' and CSC9000T management system that is the first CSR auditing standard for the industry [17]. CSC9000T focuses on labour standards which is a key part in CSR according to the authors. Although there are some tools can be used to promote CSR, without a regulatory environment and a strong commitment from the business side CSR practice can hardly be conducted. It is widely observed that in China there is an ineffective enforcement of regulations and laws [20]. Cooke and He [17] claimed that the relationship between buyers and suppliers is based on short-term benefit, and this is because of serious competition and the pressure on price and quality. Most of the companies that conduct CSR were under the pressure of multinational corporations (MNC), however there were risks for them to lose business with other counterparts that did not require CSR practices [17]. The authors also stated that there is no universal CSR standard due to the diverse codes of conduct and Chinese companies see CSR-related activities as financial burden therefore little economic incentive to encourage the implementation of CSR.

To conclude the relationship between CSR and HRM in China, it is still at very early stage while firms have no standards on CSR and the initiative is based on government pressure. Cooke and He [17] stated that Chinese textile and apparel firms have already realized the importance of CSR although many of they have no written CSR policy and obtained CSR standards. According to the authors, the driving forces to implement CSR is mainly because of enhanced reputation, improved customer satisfaction and reduced operation cost. In addition to that, those companies prioritize legal and economic responsibility over ethical responsibility. This means those firms conduct CSR in response to only the government. Although the companies reckon employees are the main stakeholders, they care little for workers' standards such as health and safety issues, child labour, wages and working hours. Cooke and He [17] also claimed that they also lack employee engagement in decision-making about CSR issues. When employees are 
involved in CSR practices, they tend to be motivated by financial incentive rather than moral initiative. It is also suggested that most of the companies have not established information sharing with other companies on CSR. Therefore no mutual pressure exists in the industry to engage in CSR activities. The reason why it is hard to implement CSR in China is partially because of few influential CSR organizations are in China [21]. Cooke and He [17] claimed that due to the weak aspects of the industry in China such as the role of the government and the incentives of the company to conduct CSR, non-government led pressure initiatives are unlikely to impact the current industry in China.

\section{CSR in the National Context}

Because of the difficulty of engaging CSR for the companies in China, it is necessary to know about the root cause that leads to the difficulty. Although 'the state's new development strategy, workers' activism and the Western-based consumer movement, more or less, can account for the enhancement of labour standards in China', 'the role of CSR is especially controversial in both academic and practitioner communities' [22]. According to the authors, although transnational corporations (TNCs) constrain their global suppliers through some soft regulations, monitoring and implementation of the codes is still problematic. Although some CSR programs enhance outcome standards, they fail to enhance process standards. The author stated that workers' wage and working conditions have been relieved, their rights to bargain is still limited. Process standards implementation still has its barrier to be conducted. This is due to the complex relationship between civil society and the state and business in China.

\section{Corporate Social Responsibility Issues in India}

The size of the market, the location, the availability of sufficient natural resources and high density of well-educated and skilled workers enables India to be a preferable location for global business [23]. Its textile and garment industry has shown steady growth and enables India to be the sixth world apparel exporter just after Bangladesh [15]. In this part, the perception of the manufacturers in India and challenges to the trade union and NGO activism in India will be discussed.

\section{Manufacturers' Perceptions}

In order to know about how CSR is implemented into an organization, the most reliable way can be going to its manufacturer side or even interviewing the merchandisers and see how the those people perceive CSR. From those professionals' perspective, the real case can be revealed about the process of CSR practices and how effective CSR is in the current situation.

Gupta [15] conducted an interview with 26 participants whose jobs ranges from production managers, merchandisers and designers to auditors. The participants admitted that very few companies are socially responsible, however all of them felt it is of importance to integrate CSR activities to benefit the Indian apparel industry. While being asked to define CSR, those participants came out with different answers.

However the common part is CSR takes care of employees and benefiting the society. Some participants argued that companies should not engage in CSR for the purpose of economic gain, instead, they should give back to the society. There are three types of CSR activities among the interviews of those participants: people focused CSR, environment focused CSR and society focused CSR.

While being asked about the benefits of implementing CSR, nearly all of the participants reckoned that CSR would benefit the whole apparel industry in India. According to Gupta [15], 
benefits of CSR can be grouped into three types: employee retention, employee commitment and company image. Regarding to employee retention, it is explained that employees are less likely to leave the company if they are treated well, therefore companies will save money and time on training new crews. Employees' satisfaction and loyalty can also be seen as the results of CSR. Regarding to employee commitment, it is believed that CSR can motivate workers' efficiency and is possible to boost work ethic. For example, simply being nice to workers can motivate them to go beyond what they used to offer, therefore benefitting the their companies. Referring to company image, people prefer a company that is socially responsible. With the time, those companies that are responsible to the society build a positive reputation and solid trust in the apparel industry. Beyond that, it is believed that implementing CSR can benefit a company in long term with economic gain. From a participant's perspective, companies do not need to advertise if they have a strong reputation.

\section{Challenges to Trade Unions and NGO Activism}

Local trade unions, international none-government organizations and CSR officers are working on better and fairer rights for the workers in the Indian apparel industry [24]. However labour rights are still being violated. In order to be successful in operating trade unions, NGOs and corporate intervention, political and historical context in India should be understood [24].

Government has the power to manage and control the regulations on social responsibility, however it is not enough to monitor everyday operations in a factory on workers struggles. Neve [24] described three issues that build up the politics of representation in India: '(1) the decline in traditional trade union activism, (2) the potential for new forms of collaboration between trade unions and NGO activists, and (3) the ability of corporate interventions, through labour standards and company codes of conduct, to protect labor's key right of freedom of association'. Regarding to the decline of trade union activism, it is mainly because lots of garment factories are located in special industrial zones such as free trade zone where labour legislation can hardly apply and trade unions are resisted. Secondly, since traditional unions who are based on ground floor are not sufficient to deal with the CSR issues posed by different actors in the garment supply chain, the collaboration between trade unions and NGOs is under discussion about whether it can address the challenge faced by global, networked capitalism [25]. However there are protesters suspected the ability of NGO-union alliances to deal with labour issues systematically and lastingly [26]. Lastly, in order to encounter the impacts of garment production on workers, lots of regulatory mechanisms are designed such as corporate codes of conduct and voluntary labour standards. However whether these standards have impacts on the improvement of worker standards is still controversial. Neve [24] stated that workers' right to speak out and peoples' ability to organize the issue right is a technical matter and are part of social relationships that can only be understood in the national context and its history.

Referring to the current trade unions and workers in India, Neve [24] revealed that young migrant workers have few time for trade unions and more importantly, they demand money and time from them who have already been suffered from long working hours. Those people prefer stable wages though it is low and they are willing to work overtime. The workforce however still approaches those unions when a company fails to pay the annual bonus. What the unions usually do is to mediate the workers and the company through organizing a demonstration in public or in front of the company.

Codes of conduct and labor standards may relate to technical issues which can improve health and safety issues. For example, improving lighting and sanitary facilities. However Neve [24] claimed that not all issues are related to technical aspects. For example FOA, the right for 
workers to bargain and strike is the political question in the political economy and historical labor struggles. These codes and standards are also found in the checking points for companies. Neve [24] suggested that FOA should be associated with workers' health and safety and it is necessary to establish a company-based committee to stand for workers' rights beyond technical issues. Those rights and struggles deny the political content and obliterate the localized history. Neve [24] stated that the re-politicization of workers' rights could be achieved through locating the historical and political context and changing the process of labour representation.

\section{Foreign Workers in the Garment Industry of Malaysia}

Although the garment industry in Malaysia produces high end products to export oversea, and workers therefore have more bargaining power comparing with countries where produce low end products with lower technology and skills, Crinis [27] argued that manufacturers in Malaysia garment industry are allowed to recruit foreign workers based on short-term contracts and those foreign workers have less power compared with local workers. They are hired in dealing with changing seasons and under the context of a neo-liberal state in Malaysia, those workers are under less protection [27]. CSR initiatives are introduced to protect labour rights, however there are grey areas on foreign workers' contract including overtime wages, accommodation and trade union membership. These issues are in grey areas since auditors are monitoring factory compliance instead of from the perspective of national labour standards [26].

According to Crinis [27], monitoring reports are confusing to readers as they are lack of the information about working conditions in certain factories. The author analyzed 6 tracking charts of 6 Malaysian factories and found that health and safety section is well established while FOA and collective bargaining is empty. Crinis [27] stated that although national labour laws are usually in line with ILO labour standards, some of them are adjusted in trade union membership and minimum wages in order to meet the needs of the manufacturing industry and the developing state. This issue relating to foreign workers worth concern as Malaysia has the largest percentage of foreign workers in manufacturing industry.

In the good aspects, the garment industry in Malaysia is a good sourcing country duo to its good performance, efficient communication and the support from the government, stable work force and most importantly in today's topic, Malaysian manufacturers attract less negative attention [27]. Workers' welfare is well maintained through codes of conduct, such as working hour requirement and paid leave due to sick, holiday or maternity. Wages are in a good condition under the responsibility of the Department of Labour, although there is no minimum wages enforcement from the government as who stated in order to create jobs and provide the capital for development [27]. According to the author, local workers though expressed the dissatisfaction on the tedious work and no rises on their payment, they felt balanced when companies provide medical benefits to their families and offer free travels. In addition to that, the interview conducted by the author showed that workers in the garment industry in Malaysia felt relieved as they do not have to work more than 10 hours and the general working conditions in Malaysia are satisfactory to citizen workers.

From the perspective of the police and immigration officials, illegal foreign workers who have no work permits are the main concern in the industry [27]. Volunteers are paid by the government to arrest illegal workers without warrants in workplaces and accommodations. However it is argued that 'paramilitary vigilantes have no place in a democratic society and should never be given power over migrant workers, already a very vulnerable group' [28]. 
To conclude, the main problems in the Malaysian garment industry from foreign workers' perspective are low wages, poor working conditions and violation of basic human rights. In addition, illegal workers are in an increasing number due to desertion, and poor working conditions exist because of the increasing amount. Since undocumented labors are not under any labour standards covering workers in Malaysia, those people tend to be vulnerable to the employers who abuse them in wages, living conditions and other discrimination [27]. To the legal foreign workers in Malaysia, although labour standards have been improved to some extent and the monitoring of factories has stopped the exploitation of Malaysian workers, foreign workers are still under exploitation. If foreign workers sign the contracts including specified rights with their employers, then the employers will be able to follow their own standards [27]. In addition to that, Crinis [27] stated that the right to organize the minimum wage is still under the domain of the nation, and overtime working is a problem as well as the violation in foreign workers joining a trade union. The author suggested that CSR does not guarantee the rights of foreign workers while Malaysia taking the advantage of other nations to the development of the industry.

\section{Gender Inequality in the Turkish Garment Industry}

Although Turkey has become a developed country in recent year, the export industry especially the garment industry still has implications on women's work to developing countries. 'With the neoliberal turn in economic policies in the early 1980s, the garment industry became one of Turkey's most important export industries' [29].

Dedeoglu [29] stated that the share of formal employment is low while according to indications there is a much higher participation of women in the garment industry. This contrast indicates that women labour in Turkey is expanding in small workshops or familial subcontracting according to the author. Informal work is defined by Chen et al. [30] as 'done by wageworkers who work without a minimum wage and assured work or benefits, whether they work for formal or informal firms'. Those workers are usually not covered by health insurance or other benefits. In addition, Dedeoglu [29] stated that women's labor in home-based work faced with gender inequality as the enhanced power of their fathers or husbands, and their physical mobility is constrained as well as bargaining power. As a result, they have to accept low wage rate and be kept out from outside. In the late 1980s and 1990, some studies on informal work in Turkey suggest the expansion of this kind of work to support the growth of export [29]. It is believed that women in informal work may build up the identity and community membership in order to obtain financial security. However women's contribution to the garment industry in Turkey is obscured and concealed. The reason is the first priority role of women is mother and wife rather than generating income that indicates their husbands are unable to support the family. Dedeoglu [29] presented that although women's informal work is hidden, their contribution to the family is important in covering household expenses and children's education.

To conclude, Turkey experienced the success of export expansion with integrating women labor into the garment industry. Increased informal jobs and unfair wages are followed by 'the adoption of structural adjustment programs and neoliberal macroeconomic polices' [29]. While unpaid or low-paid workers regard their work as helping their family or relative business, owners of the business rely on the labor resource to deal with order pressure. The flexibility of the relationship provides the competitiveness for the industry. However women in the kinship relations are unrecognized and devalued in their contribution to the workplace. Their work is invisible because of its informality and social perception on market work [29]. Although women labors stayed in the industry for years, they are not protected under the social security system. Both young and old women do not emphasize a lot on the social security 
system that can provide pension after their retirement. The author claimed that it is vital for women labors in informal work situation to register to the Social Security Institution in order to gain a future with pension and other healthcare. Employment policy and employment organization are suggested to increase the bargaining power of female workers. With the increase of the export in Turkey, informal garment work continues to grow therefore labor demand tends to be strong. However trade liberalization increases the competition among different export countries such as China and Turkey [29]. As a result, low cost labors are under searching for female workers in the eastern provinces in Turkey. The author suggested that more remote regions and towns are likely to be the emphasis on social relations and network. Plans and programs aiming at support women workers should be considered to establish official policy framework. Some policies try to achieve the outcome through reducing tax burden and increasing women employment opportunity, but as it has the same nature with informal work, little job security is brought by the policy [29].

\section{Cases of the RMG Industry in Bangladesh}

Since the late 1980s, the RMG industry has become the main export industry of Bangladesh [31]. According to Ahmed [29], the export earnings were US\$8 from the RMG industry in 2006, and this figure took up 75\% of the whole export earnings. It is estimated that the RMG industry employed more that 1.9 million people in 2005, among whom the majority is women and from poorest households in rural areas. Ahmed [31] stated that both international driving forces and domestic drivers help Bangladesh to expand its RMG industry. Bangladesh shares nearly zero rates while exporting to US or EU and the Multi-Fiber Arrangement (MFA) provides less restriction on import quotas for Bangladesh compared with traditional exporters such as China and Hong Kong [32]. In domestic context, various liberalization policies cut the average tariff rates from $89 \%$ to $13.4 \%$ from 1992 to 2006 that encourage export-orientated investment in the RMG industry [31]. The access to tariff-free raw materials and low-wage workers stimulate the development of the RMG industry in Bangladesh. The RMG industry in Bangladesh has its competitiveness from both international trade regime and domestic policy framework to maintain the position of global apparel exporter. Although the productivity is a problem remains in the RMG industry of Bangladesh, low wages enable the industry to focus on mass production to compete with countries like China and India [2]. The authors stated that since most of the female workers in the garment industry are not unionized, therefore their wage level is depressed by employers. Besides the advantage of low labor cost, the government also supports the development of the RMG industry in Bangladesh through special policy for the industry including adopting conductive investment, encouraging foreign investment, establishing export processing zones, exempting corporate taxation on profit from exportoriented business [2].

Workers in the RMG industry in Bangladesh are known as their poor working conditions that may lead to work stress and other physical and psychological problems. An interview done by Steinisch et al. [31] showed that $60 \%$ of the 332 participants are suffered from either physical demand, time pressure or worries about making mistakes. Work-related demands, interpersonal resources and work-related values are regarded as the key components of work stress in the interview. 'Work- related demands and interpersonal resources were found to be associated with RMG workers' health while work-related values seemed to be of less relevance in this respect' [31]. Besides that, garment workers in Bangladesh work long hours with low wages and are under abuses.

Although the RMG industry in Bangladesh expands and becomes the biggest national export industry, workers' rights are of concern to the world. Back to 1970s, the jute industry was the 
main power for the development of Bangladesh, however due to the depression on labour unions by the politics, labors were fighting against with the force and led to the decline of the industry United States Senate [32]. According to the report from United States Senate [32], although there are some small steps have be done to protect workers' rights including engaging in trade unions and to clarify the importance of unions, much effort still need to be put in to overcome the misunderstanding and mistrust upon unions. It is argued in the report that although labor laws are reformed in 2013 and address some of the concerns from ILO, it is lack of some important steps mentioned by ILO. The reform is criticized as not improving the union registration process easier and trade unions are required to be permitted by the government to affiliate with foreign groups such as international unions or financial assistant. The report states that some workers are afraid of joining in the unions as managers will make their life hard while other successful stories show that managers stopped physical punishment and provide extra benefits to the workers. Therefore Bangladesh still has a long way to go to meet the international standards in labor laws.

In addition to export-oriented companies, Belal [35] mentioned the importance of implementing social accounting standards into non-export oriented companies. However the current situation of civil society organizations in Bangladesh is still underdeveloped and the attitude of domestic management is generally passive. The hope then is relied on future internal trade unions and the redesign of corporate decision-making process [35].

\section{Rana Plaza}

On April 24th 2013,1127 people were killed and hundreds were injured when the Rana Plaza building collapsed in Bangladesh [36]. It is the deadliest garment factory accident in history. According to Yardley [36], the reason for the collapse is the owner of the factory Sohel Rana constructed upper floor to house large power generators and thousands of workers, and regular power failures shake the vulnerable structure of when it is switched on. Sohel Rana is reported to be arrested several days after the collapse. This tragedy spurred Bangladesh government, international organizations and foreign governments into action [34]. Safety initiatives are underway to ensure that the rest of the garment factories in Bangladesh will have a safe condition. While the report conducted by United States Senate [34] showed that 60 percent of the factories in Bangladesh were vulnerable in structure.

Before and after the collapse of Rana Plaza building, actions have been taken to remediate poor working conditions. All Party Parliamentary Group (APPG) [37] stated that the brands import from Bangladesh are aware of the risk of losing reputation after the disaster. Therefore those buyers have worked on developing CSR programs through engaging in charity and managing their supply chain ethically. After the collapse, problems such as poor working conditions, labour violation, unapproved sub-contracting and the ineffectiveness of some CSR initiatives floated to the surface again. Brands issue codes of conduct that establish standards to ensure workers' safety and rights therefore complying with the law, ethical and international standards. This action is contrary to the one motived by profit that imposes pressure on working conditions and wage rates. While some big brands interviewed by APPG [37] showed that they go beyond auditing and target some root causes leading to poor working conditions through increasing skills and literacy of the workers and subsidizing training to technicians. This will further increase consumers' expectation and reduce the risk of losing reputation.

However, some NGOs argued that current CSR programs are not able to address the problems in the garment industry in Bangladesh [37]. It is claimed that those programs are voluntary based and only address visible problems. Few brands have specific processes to integrate ethical standards into staff performance indicators and targets. While most buyers claimed 
that they embed ethical and sustainable concept into corporate culture. What needs to be noticed is if the concern cannot be leveled down from the board, CSR will just be a window dressing [37].

Another worker safety initiatives launched after Rana Plaze is called the Alliance for Bangladesh Worker Safety [34]. While over 80 companies signed the Accord, over 20 American retailers including Wal-Mart are reluctant to join and instead formed another initiative called the Alliance. Under the Alliance, members are required to share knowledge, experience, practices and to contribute to the safety fund. 'The Initiative will see members of the 37 Alliance create uniform standards for fire and building safety that will guide baseline inspections of factories that do business with the membership' [37]. The fund will be allocated to training, worker empowerment, factory inspection and $10 \%$ of it will be used to support temporarily displaced workers.

In order to help Bangladesh with inspections to reach a better working condition, ILO along with the government of Bangladesh launched a program called 'Improving Working Conditions in the Ready-Made Garment Sector' in 2013 at a cost of $\$ 24.2$ million [37]. This initiative aims at reducing the fire and safety issues of garment factories as well as ensuring workers' safety and rights covering nearly half of the garment factories in Bangladesh [34][37]. The program also provides compensation and skill training to the victims involved in the two accidents of Tazreen and Rana Plaza. It is crucial for the program to coordinate with the Accord and the Alliance to avoid duplicate effort and seek a long-term solution regarding to funding and standards [37].

\section{DISCUSSION}

Based on the cases in the previous part, it can be seen that CSR practice is still in the early stage where a number of managers and other stakeholders in the garment industry are not clear about the significance or benefits that CSR brings to a company and a society. Most of buyers in the RMG industry conduct CSR in the purpose of protecting brand name and responding to the society or the government who impose pressure regarding to workers' rights and safety or environmental issues on them. The collaboration among the buyers in the garment industry is not enough to tackle the drivers of poor working conditions, although there are some initiatives created after the tragedy happened in Bangladesh, their effectiveness in improving labour standards is still unknown. Regarding to CSR reports and codes of conduct, as these activities are voluntary, there is no formal standard on the format or content that be applied. This inconsistence reduces the accountability and reliability of the companies' announcement on their social and environmental performance. In addition, while garment buyers gaining profit through low labour costs at the price of workers poor living and working condition, most of them do not act to give back until tragedies happen. This will not only leave garment workers in a worsen condition, but also threaten their own business on the long term.

While for the government, the situation is far more complex. They are usually in a conflict situation between the pressures from NGOs who strive for better working conditions such as higher wages for garment workers and the priority to maintain the advantages of its garment industry. To different countries the condition may change vastly on the acceptance of foreign organizations' involvement, transparency and its regulations on labour rights. For example, China is somehow very sensitive to the activities of foreign NGOs regarding to cash flow, and in India bribe and fake reports are the major problems. The capacity of the government to inspect garment factories and improve poor working conditions are blamed to be insufficient from the 
previous cases. Due to this gap, NGOs and buyers tend to have more responsibility in ensuring better working conditions.

For suppliers themselves, as garment production is a labor-intensive industry and factories are mostly located in developing countries where living and working standards are poor, they usually prioritize production efficiency and profit over labour rights. Without inspection and auditing from external groups, hardly can workers' rights be protected. Even if auditing is conducted in those factories, their owners and management try to hide truth such as working hours, wages, use of child labour and abuse. The success of garment manufacturers in exploiting labour lies in the poor connection between inside workers and outside stakeholders, as well as workers' willing to stay in the factories from where they can feed their families through working long hours with low wages under hazardous working environment. Auditing process is usually conducted by the supplier through private auditing firms, however the accountability and transparency remain a problem because of the relationship of pay and work. The government especially in country such as Bangladesh protects the benefit of garment factories, as they provide the majority of the employment and are the main source for the development of the nation. Therefore garment suppliers are under an umbrella where labour rights can be hidden in order to maintain the advantages.

Trade union is a group standing for the rights of workers and against the exploit from factories. In some factories, chairman or main positions in the union are taken by the management of the factory. This structure is very likely to undermine the impact of trade unions on safeguarding workers rights. In other cases, workers are prohibited or afraid of joining a trade union, as it violates the interest of the factory especially in the areas where labour laws are not applied. Referring to foreign workers in Malaysia, they do not have the rights to join union activities therefore being a vulnerable group. As can be seen, traditional trade unions activism is likely to lose power, and this is due to the lack of connection between international NGOs and trade unions. However external posed trade unions under NGOs solve this problem through involving workers in the activity and conveying basic labour rights knowledge to those workers. However, the case in India shows that some young labors feel of not having enough time to join trade unions and some of them are even required to pay for the union fee, this increases the pressure on workers who are already in a poor condition.

None-government organizations collaborate with the government and trade unions to support higher worker standards in the RMG industry in developing countries. They somehow compensate the capacity that the government cannot provide. However in China the power of international NGOs is reduced due to the national context. So for NGOs it is vital that they are empowered by the government in conducting CSR practices. It has been argued that NGOs has limited influence on the decision making of the government though they have tried hard for the change. Without government permission, hardly can NGOs conduct CSR practices in the nation.

Garment workers are the group of people that live in poor condition with low income and high risk of being injured. With the development of the garment industry in their country, numerous employments are provided especially for women. They treat their jobs as an opportunity therefore endure poor working conditions and are unwilling to fight against the violation. Long working hours is common among garment workers in order to sustain their family. The lack of labour rights knowledge makes them more vulnerable facing factories owners and managers.

According to different cases in several developing countries, a framework is established for stakeholders in the garment industry as a guideline to implement CSR practices in order to make the company sustainable as well as bring benefits back to the society they rely on. This 
framework includes main stakeholders involved in the garment supply chain: the local government, none-government organization, garment buyers, suppliers, consumers and trade unions. The relationship and communication among these stakeholders play an important role in improving a better working condition for garment workers (Figure 1).

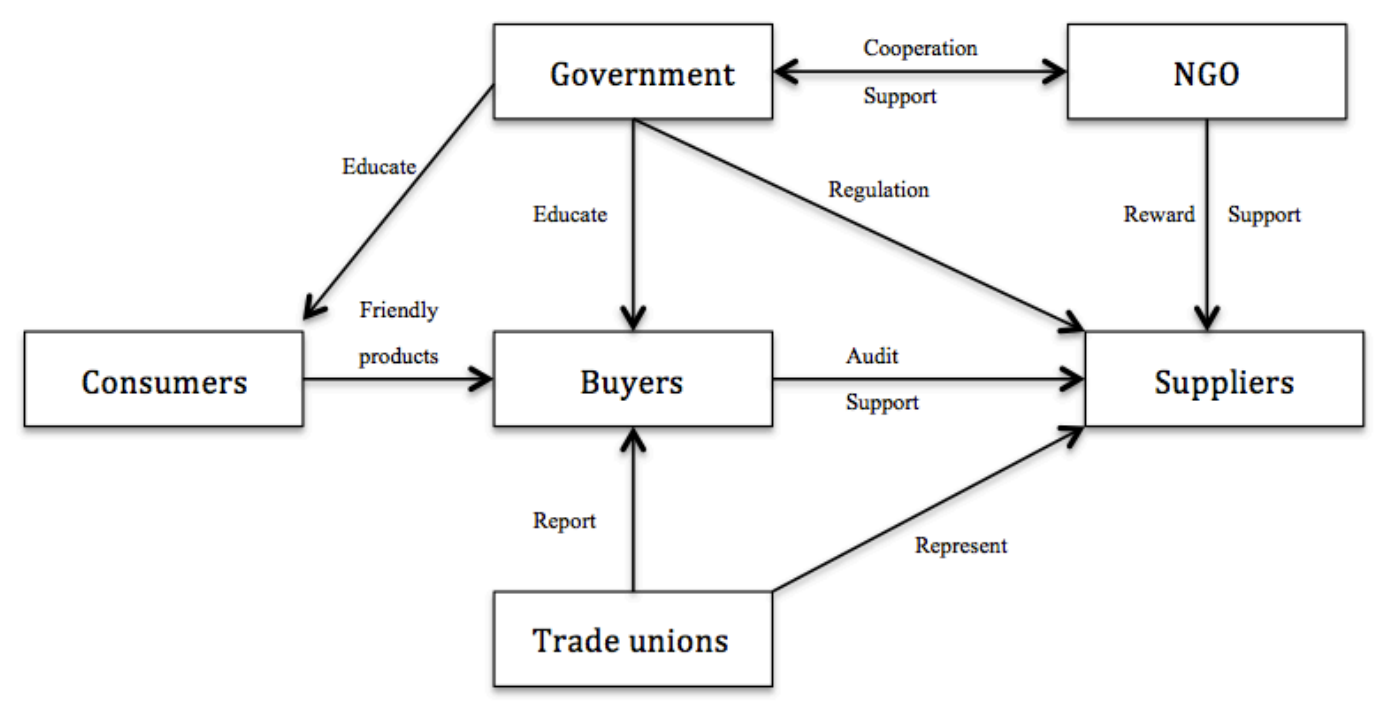

Figure. 1 Framework for Implementing CSR

Buyers are the most powerful stakeholders in the whole supply chain to force garment suppliers to stick to worker standards as they place the order that maintains the business of those garment factories. Once they terminate the relationship with the suppliers, the owners will have to shut their factories down. As can been seen buyers have a leading role in the whole supply chain. Auditing process as discussed in this study is conducted by manufacturers, however in order to increase the accountability and transparency, buyers are better to decide on their own auditing group who can be external private auditing firms. The most important part is buyers paying for the auditing that does not inform suppliers in advance. Through this process, bribe and employee and employer relationship between factories and auditing firms can be eliminated. At this point, auditors or auditing firms should be credited by the government or NGOs as of integrity. As a result, real problems can be discovered while they were hidden before.

Garment buyers have stronger power in promoting trade unions and increasing workers' bargaining power only when they are jointed. A single company does not have enough strength to change the behavior of its suppliers as they have other contractors. Based on worker safety and rights initiatives, companies that signs in workers' condition-improving program can work together with ILO to pressure garment suppliers to compliance with labour standards. A platform at where initiative members can share information about CSR and suppliers' behavior is helpful in the long-term benefits of both buyers and workers. In addition, buyers have the responsibility to keep the rhythm of orders as a sudden change in order amount lead to workers' long working hours in a certain period. Therefore the communication between buyers and suppliers is crucial to ensure moderate working pressure.

In order to be a socially responsible company, CSR practices should be embedded into its everyday activities. This action cannot leave without a manager with strong CSR sense in mind. As it is proved that managers concern about CSR issues are more likely to act socially 
responsible. Therefore educating decision makers of a company with the significance and benefits of CSR is of importance.

The local government of the RMG industry is another powerful player in the whole supply chain as they hold the right to release regulations and laws relating to labor rights. The government though sometimes is in a conflict of industry development and workers' low standards. However it is a long-term strategy for the government to set up a regulation upon garment industry in workers' safety and healthy issues as well as basic rights. The reason is if the garment industry suffered bad reputation on human rights, less orders will be released to it and thereby the industry of that nation will suffer. Minimum wage is not established in countries such as Bangladesh as to maintain the low labor cost which is the main competitiveness of the industry. However it undermines the basic rights of garment workers who have to work long hours to sustain their family. With the help of international NGOs such as ILO, the government will have fewer burdens on allocating resources into garment section. Appropriate regulations and labour laws are therefore necessary to be established to collaborate with NGOs' effort on pursuing higher labor standards.

The capacity of the local government to regulate their garment industry maybe limited, the government of the foreign buyers' has the responsible to educate those buyers to behave in a socially responsible manner. This can be seen as a giving back to the nations providing low labour cost. Through conveying CSR practices to the decision makers of a company, following actions are likely taken by those companies to highlight CSR during its everyday practice. As a result, the suppliers of them will operate under the concept of better working conditions. It is equally important to educate manufacturers to conduct CSR practices rather than simple command. With emotional communication and guide instead of force, garment suppliers are more likely to apply CSR concept in the long term rather than find another way round to hide its problems relating to abusing workers.

Trade unions can be seen as the connection between factories and NGOs or buyers directly. In some countries trade unions are weakened under the pressure of national policies or factory regulations. They are still the important component in implementing CSR practices because workers are the people who know about the real case in the factory. Representatives of workers should be encouraged to contact with buyers and NGOs to report latest condition in factories. Although auditing is conducted, the frequency is usually every few months or even longer than a year. This creates the chance for manufacturers to return to what they prefer to be. Working conditions are only improved when auditing applies and drop down continuously until the next auditing is conducted. Through trade unions, buyers and NGOs are able to know the real time information in their suppliers.

NGOs though have no legal constrain on garment manufacturers, their role in supporting the government and guiding manufacturers towards a more socially responsible behavior cannot be underestimated. In order to elevate the capacity of garment suppliers, NGOs and buyers could provide training programs to the engineers and professionals of suppliers. For example, introducing Just-In-Time, 5S and lean manufacturing to garment factories can increase the efficiency of the production and therefore alleviating workers' burden from long working hours and poor working environment. In addition, NGOs may establish a reward system to encourage those factories who are compliance with labour laws and standards. Prize of the reward can be public announcement that can increase the reputation of the factory.

In addition to the stakeholders above, consumers also have bargaining power in pursuing products that are produced under socially responsible process. Public education on using 
socially friendly products can lead consumers to choose the right products therefore changing corporation strategy towards cooperating with suppliers that are compliance with labour standards.

\section{CONCLUSION}

In conclusion, the RMG industry in developing countries is generally at fairly early stage of implementing CSR practices. Working conditions draw close attention from over the world due to low wages, long working hours, safety and health issues. In order to overcome this situation, not only the local government and garment suppliers have the responsibility to ensure workers' rights, but also brands, retailers, NGOs, and consumers shoulder the duty of better working conditions for garment workers. Garment buyers have a strong power in guiding their suppliers towards a more socially responsible behavior through auditing and financial support to increase the effectiveness and produce ethical process. While the government should educate both apparel buyers and consumers on choosing the right suppliers and products in collaboration with international NGOs and trade unions.

\section{References}

Claudio, L, Waste Couture: Enviromental Impact of clothing industry, Environ Health Perspect 2007 Sep; 115(9): A449-A454

Yunus, M \& Yamagata,T 2012, Fukunishi ed., Dynamics of the Garment Industry in Low-Income Countries: Experience of Asia and Africa (Interim Report). Chousakenkyu Houkokusho, IDE-JETRO, 2012.

ILO 2014, Wages and Working Hours in the Textiles, Clothing, Leather and Footwear Industries, International Labour Office, Sectoral Activities Department, Geneva, ISBN 978-92-2-128774-2

Stewart, KL, An ethical analysis of the high cost of low-priced clothing: Journal of Academic and Business Ethics. Dagg, IA \& Harding, L 2012, Human Evolution and Male Aggression.

On-the-go with Zimmerli in Switzerland - and that, actually, high-quality underwear is produced? http://fashionstyles.info/on-the-go-with-zimmerli-in-switzerland-and-that-actually-high-quality-underwear-isproduced/

Kozlowski, A 2012, Corporate Social Responsibility In The Apparel Industry: A Multiple Case Study Analysis, Ryerson University, Toronto, Ontario, Canada

Abernathy, FH, Dunlop, JT, Hammond, JH, \& Weil, D 1999, A stitch in time. New York, NY: Oxford University Press. Waste Couture: Environmental Impact of the Clothing Industry Luz Claudio Environ Health Perspect. 2007 September; 115(9): A449-A454. PMCID: PMC1964887

Gereffi, G 1999, International trade and industrial upgrading in the apparel commodity chain, Journal of International Economics 48 (1999) 37-70

LEAF (Labelling Ecologically Approved Fabrics); Http://leafcertified.org/the-apparel-industry.

Allwood, J.M., S.E., Laursen, C. Malvido de Rodriguez, and N.M.P.Bocken (2006) Well Dressed? The Present and Future Sustainability of Clothing and Textiles in the United Kingdom (Cambridge, UK: University of Cambridge Institute for Manufacturing, http://www.ifm.eng.cam.ac.uk/sustainability/projects/mass/UK_textiles.pdf, accessed 2 Nov 2011).

Cline, E 2014, Where Does Discarded Clothing Go, viewed 10 September 2014, http://www.theatlantic.com/business/archive/2014/07/where-does-discarded-clothing-go/374613/

Dickson, MA, \& Eckman, M 2006, Social responsibility: The concept as defined by apparel and textile scholars. Clothing and Textile Research Journal, 24(3), 178-191

Dickson, MA, Loker, S \& Eckman, M 2009, Social responsibility in the global apparel industry. New York, NY: Fairchild Books.

Gupta, M 2012, Corporate Social Responsibility in the Global Apparel Industry: An Exploration of Indian Manufacturers' Perceptions, the Faculty of The Graduate School at The University of North Carolina, Greensboro.

Sutantoputra, AW 2009, Social disclosure rating system for assessing firms' CSR reports. Corporate Communication: An International Journal, 14 (1), 34-48. 
Cooke, LF \& He, Q 2010, Corporate social responsibility and HRM in China: a study of textile and apparel enterprises, Asia Pacific Business Review, 16:3, 355-376, DOI: 10.1080/13602380902965558

Chan, A \& Ross, R 2003, Racing to the bottom: international trade without a social clause. Third world quarterly, 24 (6), 1011-1028.

Cooke, FL 2008a, Competition and strategy of Chinese firms: an analysis of top performing Chinese private enterprises. Competitiveness review, 18 (1/2), 29-56.

Cooney, S 2007, China's labour law, compliance and flaws in implementing institutions. Journal of industrial relations, 49 (5), 673-686.

Peng, L, Long, BJ, \& Pamlin, D 2005. Chinese companies in the 21st century: helping or destroying the planet? Corporate social responsibility and beyond. Switzerland: WWF's Trade and Investment Programme.

Chan, KC 2013, Promoting Freedom of Association in China? Putting Transnational Corporate Social Responsibility into a National Context, Journal of Comparative Asian Development, 12:1, 6-34, DOI: 10.1080/15339114.2013.771001

Banks, P \& Natrajan, G 1995, India: The new Asian tiger? Business Horizons, 38(3), 47-50.

Neve, DG 2008, "Global garment chains, local labour activism: New challenges to trade union and NGO activism in the Tiruppur garment cluster, South India" In Hidden Hands in the Market: Ethnographies of Fair Trade, Ethical Consumption, and Corporate Social Responsibility, Research in Economic Anthropology, Volume 28, 213-240

Braun, R, \& Gearhart, J 2004, Who should code your conduct? Trade union and NGO differences in the fight for workers' rights. Development in Practice, 14(1\&2), 183-196.

Lipschutz, R 2004, Sweating it out: NGO campaigns and trade union empowerment. Development in Practice, 14(1\&2), 197-209.

Crinis, V 2010, Sweat or No Sweat: Foreign Workers in the Garment Industry in Malaysia, Journal of Contemporary Asia, 40:4, 589-611, DOI: 10.1080/00472336.2010.507046

Kuppusamy, B 2006, “Malaysia: Bounty on Migrant Workers Encourages Vigilantes," Inter Press Service English News Wire, 9 March, http://www.highbeam.com/doc/1P1-119588745.html

Dedeoğlu, S 2010, Visible Hands - Invisible Women: Garment Production in Turkey, Feminist Economics, 16:4, 1-32

Chen, Alter, M, Jhabvala R, \& Lund, F 2001, "Supporting Workers in the Informal Economy: A Policy Framework." Working Paper on the Informal Economy, Employment Sector, International Labour Office, Geneva.

Ahmed, N 2009, Sustaining Ready-made Garment Exports from Bangladesh, Journal of Contemporary Asia, 39:4, 597-618, DOI: 10.1080/00472330903076891

Bhattacharya, D \& Rahman, R 2000, "Experience with Implementation of WTO-ATC and Implications for Bangladesh," Dhaka: Centre for Policy Dialogue, CPD Occasional Paper Series, 7.

Steinisch, M, Yusuf, R, Li, J, Rahman, O, Ashraf, H , Strümpell, C, Fischer, J \& Loerbroks, A 2013, Work stress: Its components and its association with self-reported health outcomes in a garment factory in Bangladesh-Findings from a cross-sectional study, Health \& Place 24 (2013) 123-130

United States Senate 2013, Worker Safety And Labor Rights In Bangladesh's Garment Sector, One Hundred Thirteenth Congress First Session

Belal, AR, CSR reporting in developing countries: The case of Bangladesh, Taylor and Francis GR, 2008.

Yardley, J 2013, Report on Deadly Factory Collapse in Bangladesh Finds Widespread Blame, viewed 9 0ctober 2014, http://www.nytimes.com/2013/05/23/world/asia/report-on-bangladesh-building-collapse-finds-widespreadblame.html?_r=0

All Party Parliamentary Group on Bangladesh 2013, After Rana Plaza, A report into the readymade garment industry in Bangladesh. 